\title{
Corporate land acquisitions at the intersection of lineage and patronage networks in Cameroon*
}

\author{
Frankline A. NDI \\ Department of Human Geography, Örebro University, 701 82, Örebro, \\ Sweden
}

Email: frankline.ndi@oru.se,ndihills@yahoo.com

SimON BATTERbuRY

School of Geography, 22 I Bouverie St. University of Melbourne, zо I o VIC, Australia and Lancaster University, UK

Email: simonpjb@unimelb.edu.au

and

James Emmanuel Wanki

Harvard Kennedy School of Government, 79 John F. Kennedy Street, Harvard University, Cambridge, MA, USA

Email: jwanki@hks.harvard.edu, james.wanki@gmail.com

\section{A B S T R A C T}

Despite the proliferation of literature on large-scale land acquisitions (LSLA) in Africa, few empirical studies exist on how patronage networks combine with sociocultural stratification to determine the livelihood outcomes for African agrarianbased communities. This article draws from ethnographic research on Cameroon to contribute to bridging this gap. We argue that lineage and patronage

* Fieldwork for this article was conducted as part of a larger project investigating the impacts of land grabbing in Cameroon sponsored by the University of Melbourne, Australia from 2014-2018 (grant number 381285 ). Thanks also to the University of Örebro for providing the lead researcher of this study with a research fellowship to be able to develop this article in collaboration with colleagues. 
considerations intersect to determine beneficiaries and losers during LSLA. Second, we show that LSLA tend to re-entrench existing inequalities in power relations that exist within communities in favour of people with traceable ancestral lineage. Concomitantly, non-indigenous groups especially migrants, bear the brunt of exclusion and are unfortunately exposed to severe livelihood stresses due to their inability to leverage patronage networks and political power to defend their interests. We submit that empirical examination of the impacts of land acquisitions should consider the centrality of power and patronage networks between indigenes and nonindigenes, and how this socio-cultural dichotomy restricts and/or mediates land acquisition outcomes in Cameroon.

Keywords: Land acquisition; lineage; patronage; indigenes; settlers; Cameroon

\section{N T R O D U C T I O N}

In Cameroon, social distinctions based on residence status have become a central issue in the country's socio-political system, catapulting into the politics of inclusion and exclusion. On the one hand are the 'indigenes' ${ }^{1}$, autochthones or 'original' inhabitants of an area, also called the 'sons and daughters of the soil'. In other words, these are people whose lineage can be traced to an ancestor in the community they inhabit and prior to the colonial period - and they are considered as the traditional land-owning families. On the other hand, are migrants, strangers ${ }^{2}$ (Skinner 1963) or settlers - who were once 'indigenes' elsewhere, but are now hosted by communities different from their places of ancestral origin, and to where they have little intention of returning. For simplicity's sake, we will henceforth refer to this group as 'settlers'. They are granted the right to access and use land by virtue of their social relationship with an indigenous patron. This divide lays the foundation for social exclusion for those without ancestral links in a community, constraining their effective participation in decision-making processes (Tabe Egbe-Orock 2005). This is especially the case regarding land matters. As such, community social relations are characterised by the undercurrent of a 'politics of exclusion' shaped by virtue of a people's place of ancestral origin. This division influences access and control over land and resources, especially in rural and peripheral parts of the country. This socially defined difference broadly echoes Cameroon's administrative system. It comprises a hotchpotch of highly flawed, colonially inherited bureaucratic rules, processes and institutions that operate on a divide and rule logic-and latterly co-opted and refined by the Paul Biya regime (since the 1990s-present) to effectively curtail the power of oppositional forces to compete with the ruling party during elections and in the exercise of (multi-layered) political power (Yenshu 1998; Nyamjoh \& Konings 200o). Other scholars have argued that the government uses such a strategy to exert its political control, especially in rural and peripheral areas (Geschiere 2001).

Although the question of ancestral origin is commonly debated across Cameroon, it appears most prominently in the South West Region of the 
country, where the social distinctions between indigenes and settlers have been politicised by the Biya regime in furtherance of a 'divide and rule' agenda. During the colonial era $\left(1884^{-1961)}\right.$, the South West Region experienced a massive influx of people from other parts of the country, especially from the North West Region, including groups from neighbouring Eastern Nigeria when it was advantageous to migrate across the border to seek employment in the plantation sector (Bederman 1966; Ngoh 1996; Yenshu 1998). The large inflow of these migrant groups has since then threatened some local populations in the host communities, who felt outnumbered in 'their own' region and in their villages of origin (Yenshu 1998). Although some settler populations have now lived in the South West Region for over half a century, they are still considered as 'migrants' and 'strangers' or labelled by the pejorative term 'come no gos'. ${ }^{3}$ As such, the offspring of settlers are prejudicially perceived to be incapable of claiming the full right to 'belong' since they cannot fulfil the cultural requirements of 'belonging'. For that, they would need to show proof of where their ancestors were buried.

This inability of settlers to exercise similar ownership rights over land as the local population would normally do, is indicative of a community-level power asymmetry. This unequal power relationship is further explained by the fact that settlers and newer arrivals cannot be made chiefs or traditional heads. Therefore, they are unable to benefit from the powers accorded to chiefs as constituent members of the Land Consultative Boards (LCB) - a statutory organ created by the state to manage land under the auspices of the Divisional Officers (DOs) assisted by local chiefs acting as government auxiliaries. 4 This explains the non-participation and quite often, the sheer neglect of settlers and other migrant groups during land discussions and negotiations.

In Cameroon, a few recent studies have been conducted on large-scale land acquisitions mostly examining the trends, processes, actors and institutions involved, and the disproportionate gendered impacts of this phenomenon (Fonjong et al. 2015; Ndi 2017, 2019a, 2019b; Ndi \& Batterbury 2017; Wanki \& Ndi 2019). As elsewhere in Africa, little has been documented to show how lineage and patronage networks intersect to shape land acquisition processes and outcomes in Cameroon. This article aims to close this knowledge gap. We use a case from the South West Region of Cameroon to argue that, first, lineage and patronage intersect to determine who benefits, and who does not during large land acquisitions. Second, we show that large land deals tend to re-entrench the existing unequal power structures and relationships that exist between communities in favour of those with traceable ancestral lineage. This can and does create severe livelihood stress for settlers and migrants, especially where they have little or no patronage networks and political power to defend their interests.

The remainder of this article presents the context of land acquisition in Africa. We then move to explore the linkages between land tenure, social categorisation and large-scale land acquisition in the country. We conceptualise the place of patronage politics in Cameroon followed by reference to an oil 
palm project, and we describe our methodology. The core of the article analyses the impacts of this project on loss of land between indigenes and settlers in terms of diminished livelihoods and resources, economic deprivation and food insecurity, and altered patronage networks and community social relations.

\section{The context of large-scale land acquisition in Africa}

Africa is increasingly attractive for international investment, and particularly from the late 2000 s there has been renewed interest in commercialising agricultural land and forests. The abundance of these resources is often perceived from outside the continent, in a cruel reminder of colonial times, to be 'under used' and therefore available for commercial exploitation on advantageous terms (Cotula \& Vermeulen 2011 ). Wealthy African investors and multinational companies with roots in the West, China and the Middle East have stepped up efforts to acquire land for food and biofuel production, mining, timber extraction, and even to support conservation for altruistic reasons and for profit (Zoomers 2010; Borras et al. 2011; Cotula \& Vermeulen 2011; Borras \& Franco 2013; Scoones et al. 2013; Wolford et al. 2013). The renewal of interest in conventional economic growth and poverty alleviation certainly involves a combination of foreign and national investors, and revolves around natural resource exploitation, poorly justified as fuelling growth and investment to support national and local socio-economic development in host countries. In reality, this is not the case, as most often than not, communities are dispossessed of land which they depend on for livelihoods and without alternative survival means.

Since the global food crisis of 2007-2008, there has been a huge demand for large, commercial holdings to be leased from many African countries including Ethiopia, Mozambique, Sudan and Sierra Leone. The scale of announced deals in Africa was estimated in 2011 to be in excess of 40 million hectares, approaching $2 \%$ of Africa's land area (Deininger \& Byerlee 2011 ; Collier \& Venables 2012: 1). The sizes of land deals have varied widely, with a median project size of 40 ,ooo hectares, but with over a quarter exceeding 200,ooo hectares (Deininger \& Byerlee 2011: 51). Most land deals take the form of long leases, ranging from 20 years to 100 years (Collier \& Venables 2012). Sub-Saharan Africa is the most targeted region globally for large land deals of this form, and has been referred to as the 'grabber's hotspot' (Batterbury \& Ndi 2018).

Studies suggest that land investors mainly target countries with weak governance systems as well as suitable bio-physical conditions (Cotula et al. 2014; Verma 2014). These have included several post-conflict economies. It is clear that national governments and local elites are actively involved in facilitating land acquisitions, from which they seek to benefit (Borras \& Franco 2010; Vermeulen \& Cotula 2010; Wily 2011; Baglioni \& Gibbon 2013; Cotula 2013; Kandel 2015; Millar 2015). Nonetheless, in the last six years or so, some commercial agricultural and biofuel projects have been halted or cancelled due to a less favourable economic climate, but protests against non-consultative 
land grabs continue (Cotula 2013; Millar 2015; Moreda 2015, 2017, 2018; Ndi 2017; Ndi \& Batterbury 2017). The control of land is increasingly complex and nuanced, producing a variety of outcomes amongst its users (Borras \& Franco 2013). If Africa has really become a new 'frontier' for international investment in its natural resources, then this investment is occurring unevenly, and unjustly.

On a global scale, much research investigating LSLA has explored the economic, social and political transformations it is linked to, and its overall impacts on land and forest-dependent communities (Vermeulen \& Cotula 2010; Peluso \& Lund 2011; White et al. 2012; Ndi \& Batterbury 2017). Many studies (e.g. Millar 2015; Moreda 2015; Hall et al. 2015; Ndi 2017; Ndi \& Batterbury 2017; Wanki \& Ndi 2019), have responded to Marc Edelman's call to undertake research that is more micro-focused and historically grounded (Edelman 2013), in order to have a better understanding of the on-the-ground realities accompanying large land acquisition. In Africa, even though lineage and patronage networks are understood to shape large land acquisition processes and outcomes at the grassroots, analyses of these remain scanty (Bueger \& Mireanu 2015). Ryan's (2018) research in the extractive industries in Sierra Leone has echoed this concern; urging researchers to conduct empirical studies examining local impacts occasioned by the loss of land for commercial agriculture. These concerns reflect a long tradition of 'disaggregating' the impacts of agrarian change in Africa, showing how community peoples experience different outcomes (Berry 1984; Bryceson 2000; Peters 2004). In an attempt to contribute to the literature on the 'politics from below' when land is lost (Hall et al. 2015; Moreda 201 7), this study focuses on how patronage networks and lineage intersect with one another to produce disproportionate outcomes amongst communities who largely depend on land and forest resources for livelihoods. It shows how large land transactions by corporate entities reentrench existing asymmetrical power relationships amongst community actors by virtue of their 'place of ancestral origin'.

\section{Conceptualising the place of patronage politics at the grassroots in Cameroon}

In his compelling text on comparative politics and historical sociology entitled The State in Africa: The Politics of the Belly (1989), Jean-François Bayart employs the theoretical prism of patronage to excoriate the political waywardness of postindependent African regimes. He borrows the Cameroonian political idiom 'politics of the belly' to capture the patron-client relationships that pervade politics, with particular reference to Central and West African regions. The term refers to a context where politicians and other political elites distribute goods and favours - filling the bellies of their clients from the largesse of State coffers in return for their political loyalty in ways that wholly obviate the need for entrenched democracy, good institutional governance and accountability. The politics of the belly is thus very much akin to what political scientists casually refer to as 'Cabritismo', a term loosely translated to mean "a goat will eat where it is tethered" (Moorman \& Pitcher 2014). In all its ramifications, patronage 
politics could therefore be understood as the transactional re-arrangement of politics and governance modalities based on what Cromwell \& Chintedza (2005) describe as 'the giving and granting of favours'. In the context of large-scale land acquisitions, this helps explain the role and interest of local elite and traditional authorities, and their willingness to do the bidding of foreign land investments at the behest of government officials and other interested parties.

With respect to Cameroon, at the analytical core of Bayart's socio-historical treatise on patronage politics is an insistence on the need to dissect the politics of belonging, 'the vertical relationships between social unequals - patrons and clients' (Thomas 2003), the greed and predation of the political class, and the ways in which neopatrimonialism, clientelism, corruption and power collide to blight the country's body politic and imperil prospects for consolidating democratic governance. Successive post-independence regimes in Cameroon (the country has only known two in its 6o years independence history-that of Mr Ahmadou Ahidjo and subsequently, the current Biya regime) have grappled with the challenge of maintaining centralised political power in a country known for its dispersed but strong ethno-political allegiances. For Ahmadou Ahidjo, the solution was to create a highly personalised and authoritarian patrimonial state reliant on the establishment of 'a hegemonic alliance out of the various elite groups in society which were given access to State resources and rent-seeking activities so as to cement their loyalty to him' (Konings 1996). As Konings (1996: 248) has reiterated, the Ahijdo hegemonic alliance 'comprised not only of politicians, bureaucrats and businessmen but equally the traditional elite, the chiefs ... a heterogenous coalition [from which] a new dominant class was slowly emerging around the State'.

But with the advent of multiparty politics in 1989, the Biya regime faced a new set of challenges simply unresolvable by the sheer authoritarianism and repressiveness of the Ahidjo era. It recognised the inherent but delicate challenge of liberalising Cameroon's political space to make room for the flourishing of more diverse and enterprising party politics (as a means of fulfilling IMFWorld Bank conditionalities for political liberalisation), while at the same time maintaining full political control over the levers of power in the country. To accomplish this fragile balance, the Biya years have seen his CPDM [Cameroon's People Democratic Movement] party being fastidious about deepening and broadening its infiltration and control over ethno-localised spaces in the country, with an extensive use of patronage politics to secure the unconditional loyalty of local elites, traditional rulers and grassroots communities. This is particularly the case in the South West Region of Cameroon.

As Geschiere \& Konings (1993) have noted, this co-optation of local elites and traditional authority has been partly facilitated by a commonplace understanding that the State is a resource base from where loyalists can harvest personal pecuniary gains and communal windfalls; especially as 'the state retains a substantial monopoly over the effective channels of provisioning resources 
for local development' (Tabe Egbe-Orock 2014). In the transactional calculus of patronage politics, the rules are simple: traditional authorities and local elites serve as harbingers of regime loyalty, they mobilise the allegiances of community members in defence of the government's agenda, canvass and secure votes during elections, draft motions of support to the Head of State, and facilitate the exercise of the will of the government and senior government officials. In return, the regime rewards traditional authorities and local elites with political recognition, personal gains and development projects for their communities. In fact, as a former Anglophone Prime Minister Peter Mafany Musonge, an elite of the South West Region once reiterated in a meeting with his local constituency, 'we must scratch President Paul Biya's back so that the President could continue to scratch the backs of South-westerners'.

Yet, a pertinent dimension of the workings of patronage politics and the politics of belonging in Cameroon that deserves closer attention here has to do with increased efforts by agents of the Biya regime to widen indigene-settler divides through the instrumentalisation of ethnicity, especially in the two Anglophone regions of the North West and the South West (Konings \& Nyamnjoh 1997: 212). In the South West Region in particular, pro-government politicians, elite and traditional rulers have sought to curtail the numerical strength and entrepreneurial spirit of North-westerners (who first arrived as labourers to service the needs of the plantation economy established by the Germans between 1884-1916 and settled) - through deliberate attempts at alienation and discrimination. Pejorative discourses such as 'come no gos' refer to people of North-western origin currently settled in the South West Region. Another has been through the blaming of North-westerners for the political and economic misfortunes of South-westerners. For example, Oben Peter Ashu, a prominent South West agent of the Biya regime and then Governor of the South West Region famously declared in a Radio Buea interview in January 1996 that the poor performance of the CPDM party in his jurisdiction in the 1996 municipal elections 'could be attributed wholly to the settler population who voted for the opposition' (Konings \& Nyamnjoh 1997: 212).

Another, and perhaps a more consequential approach has been manifested through the insistence on ethnic belonging, ancestral origins and cultural affinity by certain South-western elites and traditional rulers as conditions for accessing land, forest and other community resources, effectively marginalising settler communities. This illustrates the strategic role that patronage politics plays in the current widening of the indigene-settler divide at the grassroots, in ways that fracture the fomentation of a unified Anglophone ideology or platform of resistance against the Francophone dominated CPDM regime. For the regime, this is an even more crucial political strategy at a time when greater Anglophone agitations for autonomous rule have experienced a remarkable revival since the 199os. Against this contextual backdrop, it becomes clearer who the losers are within communities experiencing largescale land acquisitions in south-western Cameroon, and the ways in which their position of victimisation is perpetually reinforced and compounded by 
several considerations, at the centre of which lie patronage politics and lineage networks.

\section{Land tenure, social categorisation and land acquisition in Cameroon}

In precolonial Cameroon, land ownership and management were in the hands of local people. Chiefs and/or family heads were considered as the custodians of village land. Land was, and still is, seen as an ancestral gift, held in trust for future generations (Fonjong et al. 2010). This means chiefs and family heads acted as trustees to allocate portions of land to local people for various uses such as farming and settlement. Individuals had no right to dispose of this land without the consent of local chiefs or family heads (Mabogunje 1981). Most importantly, in many rural communities, customary law generally prohibited the selling of land to people outside of their community (Joko 2006; Fonjong et al. 2010), and there were few land pressures (Ruel 1969).

During the colonial and post-colonial era, beginning in this region in the 189 os under German occupation (Ruel 1969) the systems of land ownership and management took a different turn. Colonial and post-colonial governments of Cameroon introduced a series of legal reforms, which continually supported the growth of private land ownership. For instance, the 1974 and 1976 land laws were aimed at encouraging individuals or corporations to legitimate land claims through the acquisition of land titles. To reinforce these legal statutes, the government passed a decree in 1976 to nationalise all land whether or not it was effectively occupied, except private land with valid registration documents, and state land (Decree No. 76/165 of 27 April 1976). As per Ordinance No. 74, land was classified under three categories: national, state, or private land. All untitled land, including that under customary tenure without land certificates, falls under the category of national land, for which the state is the guardian (Section 14 and 15 of Ordinance No. $74^{-1}$ of 6 July 1974); but local communities continue to retain their customary right to use land. The lands within the private property of the state are indeed owned by the government.

The strategy of nationalisation and titling, which followed similar degrees in other African states, was motivated by the desire to promote private sector development, good governance, peace and social development, as well as to generate income through taxation. Ngwasiri (2001) argued that land formalisation and certification in post-independence Africa is simply a reproduction of colonial systems that enable the appropriation of land and resources by the wealthy and educated class especially in the rural areas, and that some local chiefs are instrumental in the process. Put simply, the emergence of land market favours those able to purchase land and to speculate, in principle overcoming 'place of ancestral origin' as the major criteria for land access. Similarly Boone (2013) contends that across Africa, land formalisation and certification is part of the process of internationalising capital, and that, in this process, land 
is capitalised, commodified and potentially placed on the international market for competing buyers, unless national laws forbid this.

In Cameroon, the formalisation of land tenure and ownership has given birth to new institutions, followed by changes in the mode of governance over land and forest resources, as well as the unintended establishment of conflicting hierarchical structures of power and control. For instance, issues concerning the management of national land were placed under the National Land Consultative Boards (LCB) as indicated above. Thus, all non-registered lands are considered national lands according to Section 4 (1) of Ordinance No. 77-1 of 10 January 1977. Consequently, most land in Cameroon designated as 'national land' actually consists of untitled land including communal land held under customary law, and most of this is, as it was in the past, used by communities for productive and consumptive purposes. Thus, the ability of the government to exercise full control and authority over untitled land gives it the authority to make it available to land investors upon request, sometimes for up to 99 years. This confirms the observation made by Cotula et al. (2014) that in many African countries, land constitutes a major political asset, and that state control over land enables rent-seeking and political patronage by large corporations, politicians, wealthy businesspeople, chiefs and other influential community members. In Cameroon, in the case at hand, a company called Sithe Global Sustainable Oils Cameroon (SGSOC) approached the national government seeking land for oil palm production, and with the help of some chiefs and local politicians, land was acquired without the consent of traditional owners and users.

In Nguti sub-division of South West Cameroon, access to and control over communal land is traditionally mediated through lineages -i.e. through networks of social relations, in which ancestral status bestows rights and obligations. Despite the assertion of national ownership since the 1970s, these rights and obligations are generally respected by local communities, in the absence of external interventions in the land market. As a result of social differentiation by virtue of lineage, most 'stranger' populations in Nguti subdivision (Figure 1) lack the political and cultural power to lay claim on the land they use. This explains why during the recent land deal deliberations, settlers and migrant populations lacking political power were almost never invited to community discussion meetings, despite constituting a significant percentage of the actual land users, and being the group most affected by the government's plans to enable land acquisition.

\section{SGSOC's project and study methods}

SGSOC is an oil palm plantation project, founded in 2009, and formerly owned by Herakles Farms, a US agribusiness company. Between 2015 and 2016, a British businessman, Jonathan Jonson Watts, took over SGSOC's management. The project initially occupied an area of 73,086 hectares of forest and existing farmland, that has a population of at least 25,000 people (Nature Cameroon 


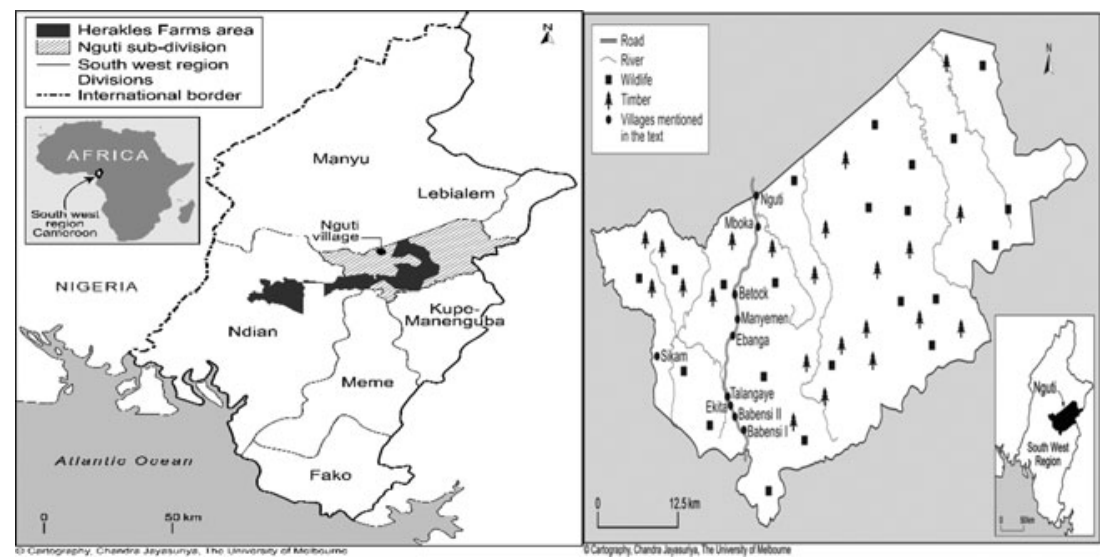

Figure 1. Map of the South West Region of Cameroon, showing selected villages in the Nguti sub-division, and the area covered by the original Herakles Farms Project (SGSOC).

2011 ). From its inception in 2009, residents contested the project, arguing that it would deprive them of their farmland and sources of livelihood. International and national organisations also called for the annulment of the project because of its environmental effects, and social and economic injustices for affected communities. In reaction to numerous appeals and protests, the President of Cameroon signed a decree in 2013 downsizing the company's concession to 19,843 hectares. Communities were already dispossessed of their farmland, and forests were cut, and the timber sold to create plantation concessions (Nature Cameroon 2011; Hoyle \& Levang 2012; Nguiffo \& Schwartz 2012; Greenpeace USA 2013). The company stopped operating in 2017 due to the ongoing violent conflict in the region, but formal access to the land it acquired has not been restored to communities because the state has warned them against trespassing; and doing anything contrary will be at their own peril.

This study combines data from focus group discussions, semi-structured interviews and field observation conducted from March-November 2015, and a return visit for one month in January 2017. While the oil palm business is currently on hold, fieldwork was conducted at the height of concerns about land grabbing and forest loss, and the micropolitics of palm oil production are representative of similar grabs still occurring across the region. The communities researched included Babensi II, Nguti, Manyemen, Ebanga and Talangaye (Figure 1). About 1 oo interviews were conducted with men and women (semi)subsistence farmers, small producers, hunters and harvesters of nontimber forest products (NTFPs). Some interviews were conducted informally due to the sensitive nature of this topic in the region. In addition, at least two key respondent interviews were done in each village and with village heads or local politicians, each lasting about 60 minutes. Two focus group discussions were held in each village: one with women and one with men, and 
representative of those with and without ancestral ties. We asked people about their social, cultural and political ties in communities; how and what they knew about the company and its dealings; whether or not they participate in its activities; whether or not the project was impacting on their life, and how; and if alternative livelihood options were made available. These questions helped us to ascertain people's social ties and relations in communities; but to also understand the processes and actors involved in land acquisition; whether or not communities were consulted, as well as the disproportionate impacts that generally follow when land is acquired. Our discussions with village heads, local politicians and state officials dealt with complex and often conflictual issues - how land was acquired; those involved; the roles they played; alternative community livelihood options; challenges that emerged; and how issues were resolved between and within communities, but also between communities and the state and investors.

Primary data were complemented with critical review of peer-reviewed literature on land tenure reforms and ownership rights in Cameroon; commercial agriculture, gender, food security and livelihoods; and power relations in the context of agrarian change in Africa, focusing on Cameroon (see for example Fonjong et al. 2010, 2015; Mope Simo 2011; Fombe et al. 2013; Ndi \& Batterbury 2017; Wanki \& Ndi 2019; Kaushal 2020). Secondary data were also elicited through the review of published and unpublished non-academic and technical sources including reports from national NGOs such as Nature Cameroon, but also from international organisations such as the WWF, Greenpeace, FAO and the World Bank. These sources allow us to have a grounded understanding of how patronage and power can reposition social actors and communities during land deal negotiations; and how different impacts are created between indigenous and settler groups in communities.

\section{Loss of livelihood}

Large-scale land acquisition in the South West Region of Cameroon occurs at the frontier of rural societies - the same places in which community wellbeing and traditional land-based social relations are deeply rooted (cf. Ndi 2013). The rural population is diverse, not only in terms of ancestral status, but also in terms of age, gender and primary livelihood activities. The land targeted for acquisition is used by the Bakossi, Bassosi, Balung and Mbo ethnic groups to cultivate food crops such as maize, beans and cassava; and cash crops like cocoa, coffee and oil palm, some of which are in strong demand in international markets. Apart from the economic benefits of land (which is of prime concern to settler populations), land also supports socio-cultural values, belief systems and practices, and these are of great significance especially to the study communities. According to the people of the four ethnic groups, their ancestral land also contains shrines and sanctuaries, linking them to their ancestors. Consequently, any threat to land and forest resources is a threat to livelihoods. Commenting on the importance of land, a village head posited: 
Apart from the economic benefit derived from our land, it is also home for our shrines and sacred places. We need to protect these places. (10 January 2017)

Communities in Nguti subdivision complained that they were merely informed in 2009 that the state has allocated part of their land for oil palm plantations. This is not surprising given the power wielded by the government; but also, because the state uses its prerogatives as the guardian of all national lands as prescribed in Ordinance No. 74-1 of 6 July 1974, including those claimed by communities for generations for production and subsistence.

Communities reported that the state, in collaboration with some chiefs and local politicians took the decision to allocate lands without proper community consultation. Local government officials insisted that most of the allocated land was 'empty' or 'unoccupied', hence a property of the state, which it could allocate for developmental purposes. Villagers find the argument that there is 'empty' or 'unoccupied' land, in either the colonial or the contemporary period, to be incongruous because land was/is used by them over generations to grow seasonal food crops and vegetables, harvest NTFPs, or was/is fallowed to regain soil fertility. Similar arguments have been put forward amongst community peoples in the Littoral Region of Cameroon (Pemunta 2014). This sentiment was especially strong during the peak of land grabbing in Nguti subdivision.

The government sold our land without asking for our permission ... this is very bad ... how do we survive? ... We depend on this land to grow crops and harvest forest vegetables to take care of our families. (15 November 2015)

Interviews and discussions held with individuals and groups reveal that women in general were the most affected by SGSOC's project because of their reliance on land to harvest forest items, but also because of their socio-cultural role in ensuring local food production. Women in settler households were badly affected because they were often not considered for compensation, when any was offered or promised. Even in cases where women from a settler background intermarry with indigenous men, we were told those women still do not command full access rights to land because the society is patrilineal-and women's access rights to land are derived from men. Thus, settler women had access to very limited land parcels compared with women with ancestral links. We were told that through the influence of chiefs and their networks, almost all men and women with ancestral claims were promised compensation for crops destroyed. However, the few who had received compensation at the time of fieldwork claimed that the amount received was far less than the value of their crops, even for that year. A few were compensated, despite the length of time of their occupancy, but settler groups were not. This magnified the power asymmetry among the community, but also the power of patronage.

As a stranger woman, life will be very difficult for my family ... my husband has no stable income ... my cassava farm was destroyed without compensation. (10 January 2017) 
'... This is my village, we struggled very hard with this company before they could give us some little money ...' A respondent from a chiefly household commented (9 September 2015).

These quotes reveal the degree of suffering affecting the wellbeing of communities; but also point to the fact that the impact of the loss of land is disproportionately felt between indigenous and stranger households, and especially by women [or-cutting across these categories, the loss of land has gendered dimensions]. The nature of crops grown by women and their cultural responsibilities to focus on subsistence crops places stranger women in a more precarious situation when dispossessed than those with ancestral links who can work through their chiefs or local politicians to obtain alternative farmland. During fieldwork, about $30 \%$ of all indigenous men also reported that they had limited possibilities to expand their cocoa farms because parts of the forest reserved for future use had been acquired. Over $60 \%$ of men from stranger/migrant backgrounds lost their farmland because they were never part of the negotiation, but also because they are not considered as having traditional rights to ancestral land, and so could not be part of the 'few' who were contacted during deliberations. Consequently, most strangers/settlers lost land to SGSOC without securing alternative sources of livelihood from the company or the state (cf. Ndi 2017; Ndi \& Batterbury 2017; Batterbury \& Ndi 2018; Wanki \& Ndi 2019). In sum, without stronger patronage networks and political power, settler households tend to be more vulnerable to land acquisitions compared with indigenous populations.

\section{Economic deprivation and food insecurity}

Communities and individuals in the region decried increased economic hardship caused by the loss of land for the oil palm business. Employment was promised by the company to everyone living in the subdivision who was willing and able to work. But because the company was at its initial phase of development, and its investment plan proved too ambitious and there were management and financial issues, there were fewer jobs than the number of people seeking employment. For this reason, the majority of those first employed had ancestral links. Those employed complained of extremely low salaries paid by the company. Some argued that the cost of losing land exceeded what they received as monthly salaries. The unemployed considered the project to be detrimental to their wellbeing, with the settler population badly affected. The distribution of compensation packages reasserted the patronage networks of indigenous people over and against the settler population, reinforcing social inequality. Moreover, many indigenes whose land was acquired were in a less precarious situation as some were promised compensation for crops destroyed; but also, because they have the political opportunity as ancestral landholders to negotiate for alternative farmland through their chiefs and local politicians. 
Interviews and discussions with settler households revealed that the majority were unable to pay their children's school fees because of restrictions on access to land and forest resources. The issue of non-consideration for compensation was raised more often by settlers who, we noted, were bypassed in the process partly because they received little or no support from chiefs and local political elites, and partly because of their 'stranger' status. This does not imply that all of those with ancestral claims received compensation. Less than $10 \%$ had received something-mostly chiefly households, and over $80 \%$ of respondents complained that they had received nothing. But the point is that, most of the people who were promised compensation by SGSOC were those with ancestral rights and stronger networks and influence. The following statements were frequently voiced by people without ancestral ties:

As a migrant, it is difficult for me ... I lost my only piece of land ... I received no compensation after my crops were destroyed. (25 August 2015)

Settlers were not considered for compensation partly because they did not have the networks or people in authority to protect their interests. And since lineage determines who has the traditional right to land ownership, it also mediates the economic experiences of those dispossessed of land and related resources in favour of those with local ancestry. Some indigenes did confirm that they received compensation for crops destroyed even though the amount was insufficient. As one commented:

If I was not related to the chief, this company would not have paid for my crops ... The amount was small ... but, better than nothing. (14 October 2015)

The loss of land has triggered competition over left-over land parcels in many parts of Africa, including Cameroon (Ndi \& Batterbury 2017). Investigating this phenomenon in other regions of Africa, Cotula et al. (2014) observed that land tussles involving villagers occur through a variety of means, including political patronage and allegiances. In our case, those with ancestral rights lobbied chiefs and community patrons to request leftover land from oil palm development to grow crops. This possibility of regaining limited available land parcels through patronage networks further empowered them over other community members without such networks, who became landless.

Communities also complained to us of the inability to provide enough food for their families. Some of those with formal employment reported that the monthly salary was insufficient to cater for food and necessities. Other respondents reported a drastic reduction in the size of land parcels needed to sustain household food production; and they have resorted to buying more food and other locally produced items from outside their communities. All communities were very dissatisfied because buying food items produced from elsewhere was relatively more expensive. Many complained of their inability to consume three meals per day; a situation that was very uncommon before the establishment of SGSOC, given the rich tropical soils and abundant rainfall in the region. Consequently, food security, or access to food in the context of large-scale 
land acquisition in Nguti subdivision has two components: a lack of sufficient food, due to the scarcity of cultivable land after acquisition; but also, because people were unable to afford commercial food from outside their communities. As one female farmer said:

I do not have enough space to grow food... Items like rice and vegetables from Kumba are very expensive ... Bushmeat has become very expensive too. (10 January 2017)

Her words are a euphemised version of the many stories surrounding peoples' lives and the frustrations they encountered daily as a result of the loss of land to SGSOC. While the communities as a whole experienced serious economic deprivation and food crises, the situation is most prevalent among settler groups without strong local patronage networks to support their interests or negotiate access to remaining farmland. The economic deprivation and food insecurity caused in Nguti subdivision, today accentuated by the political crisis affecting the English-speaking regions of Cameroon, is a common trend happening in many parts of the developing world where access to land and other environmental services is determined by more powerful actors, including the state. Food security for communities is therefore mediated through networks of community social relations and the state. This negatively affects the livelihoods of community peoples, especially settler groups without long-standing power and patronage networks.

\section{Patronage networks and community social relations}

Even though there is no requirement under Cameroonian law to obtain communities' free, prior and informed consent (FPIC), one would expect that a project of this magnitude that has direct and visible socio-economic and environmental impacts on communities would at least appeal to the conscience of the state [and other actors such as the church]. While the government appeared to recognise the need to obtain FPIC from communities in SGSOC's project areas, previous research in the region suggests that the process was largely ineffective and skewed towards political allies and other key interest groups (Achobang 2013; Fonjong et al. 2016; Ndi 2017). The government has deliberately evaded controls on international investments that seek to foster the interest and rights of traditional landowners/claimants. For instance, in 2011, critics of the SGSOC project filed a formal complaint with the Round Table for Sustainable Oil Production (RSPO) citing inadequate environmental impact assessment procedures (Linder 2013). As a reaction to this, in 2012, the company withdrew its membership from RSPO arguing that the grievance process was causing delays to its operations (Achobang 2013; Linder 2013; Ndi 2017). As such, during SGSOC's land negotiation, the government demonstrated sweeping political authority over all national lands. Where grassroots consultation was in sight, the process was mostly dominated and mediated by influential local community actors by virtue of their lineage, and through patronage networks. 
In principle, large land concessions are granted to investors after conducting a thorough environmental and social impact assessment (ESIA) in and around earmarked communities. All agreements should have an FPIC. Also, the acquisition process ought to incorporate a joint decision between the government on the one hand, and local communities on the other. Agreement is needed on whether or not land should be allocated, and for what purpose (cf. Hoyle \& Levang 2012; Ndi 2017). Local peoples and other interested parties need opportunities to consent to or challenge proposals. But due to the absence of enforcement mechanisms, this did not happen with the land acquisition project signed in 2009 between the Cameroon government and SGSOC. We discovered that land deals were negotiated and signed by a few community chiefs, local politicians and other influential people without proper community consultation and ESIA.

On 27 July 2010, communities including Talangaye, Manyemen and Ebanga, for instance, approved the poorly drafted memorandum of understanding (MoU), and thereafter, allocated land to SGSOC. Fieldwork in these communities revealed that a chief from one of them was strongly behind the establishment of SGSOC in the region. We were told he used his cultural power as custodian of village land, but also his political connections with the regime in Yaoundé (the political capital) to influence the process against the wishes of many. This perhaps explains why his village was amongst the first to approve the land allocation.

A traditional head (requesting anonymity) from one of the communities above revealed that some of his colleagues had received bribes from SGSOC. The village head commented:

This company is very corrupt. They are using bribes to deceive our people. (2 1 July 2015)

Government officials, politicians and chiefs were invited to deliberate over land on our behalf which is wrong ... I hear our chief already signed an MoU with them. (Comments of another community member, 18 August 2015)

My parents migrated from the North West Region ... when this company came to this village, no one listened to us since we are not originally from here ... I lost part of my land. (Comments of a settler, 18 August 2015)

These quotations show how poor the consultation process was; but also revealed that it was corrupt, elite-dominated and top-down - where a handful of people were consulted (mostly a few traditional leaders, local political elites and people with ancestral links seeking personal gain) to decide the fate of the vast majority. Earlier studies conducted in the region have reported that the approach used by SGSOC was problematic, and the saga of this failed enterprise is reported there (Fonjong et al. 2015, 2016; Ndi 2017; Ndi \& Batterbury 2017; Batterbury \& Ndi 2018). We observed that a significant majority of people did in fact question the alleged developmental agenda of SGSOC's project.

Qualitative fieldwork in Nguti subdivision showed that the company experienced strong resistance from communities. Some presented stronger terms 
and conditions that the company should fulfil before they could gain access into village land. The people of Nguti, for instance, proved to be more informed about agro-plantation projects. Theirs is a town with strong trade links dating back to the dawn of the 2oth century, and previous experience with timber extraction companies and commercial oil palm production. During interviews, we were told that they invited consultants and lawyers to negotiate on their behalf. Communities wanted to be given the opportunity to determine the choice of land to allocate to the plantation company. For instance, they suggested allocation of land in the Mbo hinterlands, 5 but the company refused, arguing that the area is below sea level, and would not be good for oil palm. This claim warrants closer scrutiny to ascertain its validity. This is very important because many large land acquisitions are often dominated by the argument that investors acquire marginal and 'unused' land. But the assumption of 'unused', or 'empty' land is a fiction in this context, as it is across many countries in Africa (Borras et al. 2011; Pemunta 2014; Peters 2004). Investors are attracted to land with fertile soils, higher rainfall, market proximity and access to irrigation (Cotula et al. 2009; Vermeulen \& Cotula 2010). An indigenous landowner from Nguti town commented:

this project cannot hold unless we negotiate on favourable terms and they prove to us that they are developmental. There is vast land in the Mbo hinterlands. (18 November 2015)

The point here is that because Nguti has wider and stronger patronage networks, community members had stronger bargaining power with land investors. However, it is fair to also acknowledge that these patronage networks do not reflect the interests of most settlers in the community. For example, most land located in the peripheries of the region, far from infrastructure and roads (like the Mbo hinterland) is used mostly by settlers to farm, hunt and harvest NTFPs. Consequently, making such land available to land investors potentially puts the food and livelihood security of those vulnerable groups at risk. Poorer community people are heterogeneous in character and needs; but have a common interest that revolves around maintaining access to land and forest resources - their primary sources of livelihood.

Although some villages had signed MoUs with SGSOC, we noted that the contents of these MoUs were known mostly by chiefly households, local politicians and a few influential community actors. During interviews and group meetings, many people attested that they were not familiar with the content of the lease agreements. They said that the only documents they signed were to request compensation for crops destroyed by land clearing, and not the MoU. In other words, non-chiefly households and other migrant communities reported that they had not seen or did not have a copy of the lease-granting agreement. This is not surprising due to the asymmetric power relations between chiefly and non-chiefly households; but also, because settlers are not considered important in the negotiation process. Thus, power and decision making in relation to who participates during large land negotiations is, as we have shown, determined by 
lineage (whether or not you are the 'son or daughter of the soil') and patronage networks - the ability to command social, financial and political power, but also the network of relationships a person has, that can influence others.

Furthermore, in Babensi II village, our respondents complained that the company was operating illegally-without an FPIC from villagers. This assumed illegality is a result of the fact that Babensi II village was not earmarked by the government to allocate land, and neither had there been any ESIA conducted. Speaking to community respondents and their village head, no one acknowledged having seen or signed any MoU with SGSOC. Yet, their land was under occupation. As in other villages, some people in Babensi II seeking compensation for crops destroyed were asked to sign documents which were later taken to be a MoU. We noted that these illegal acts were perpetrated by some community leaders in complicity with the state, to acquire land on behalf of the company.

Thus, the power imbalance between 'sons and daughters of the soil' and settlers was, and remains, glaring in the region. This imbalance is also reflected in their patronage networks. During group discussions, it was evident that only particular individuals (mostly ancestral landowners) would respond to questions regarding whether or not to cede land to SGSOC. We could ascertain the sheer silence on the part of settlers for fear of being adversely affected or singled out by landholders or state officials. Most often, settlers would rather speak to the lead researcher in private while ensuring that their identities were kept anonymous. Exhibiting silence during public discussions is an expression of a lack of security, and of the workings of patronage. Meanwhile, those who spoke [more] freely were either from chiefly households or landholders, or those having relations with the chiefdom or local politicians and/or government officials. Thus, relations of power between indigenous and settler groups are re-entrenched not only through the ability of landholders and their chiefs to support (or refuse) land allocation to investors, but also through the symbolic capital generated by exercising decision-making power when engaging in major land negotiations. Since settler households are not considered landowning families, they are denied de facto the opportunity to actively engage in land negotiations.

The loss of land to SGSOC in particular (and the recent conflict of separation between the Republic of Cameroon and the former West Cameroon, aka Southern Cameroons or Anglophone Cameroon, hosting this project) has precipitated outward migration in the region, especially by women from settler households. We observed that these women commuted to work for people owning large cocoa farms or looked for land elsewhere to cultivate and/or harvest NTFPs. Some have begun petty trading, selling cooked food, while others buy and sell food items. This feminisation of migration especially amongst settler women is a new trend in the region. Before SGSOC was established, men predominantly migrated to other neighbouring villages to farm, or they moved to the city to look for jobs. Many respondents reported this trend to be problematic because men often argue that culture prescribes that 
women cook and cater for children. While livelihood diversification offers many opportunities, it also brings high levels of financial and personal risk, and threatens traditional agrarian and family structures (Bryceson 2000). The degree to which land was acquired has significant influence on communities, especially among semi-subsistence settler populations in the region.

It is not my duty to cook and look after children. My wife has to. (Comment of a male settler, 11 January 2017)

the loss of land has made women poorer ... no way to freely access the forest and harvest vegetables. (Comment of a female settler, 20 January 2017)

D I S C US S I O N

The anatomy of conflict 'which arises between Africans indigenous to an area and 'strangers' - those groups which for various reasons had moved out of their homelands and had established relatively long-term residence in the territories of other groups' (Skinner 1963: abstract) runs deep in African society and preceded the colonial presence. In most cases, as described here, 'settlers' are denied rights, and operate through rights 'derived' from their relations with the original inhabitants. These conflicts and negotiated social positions are, to an extent, a cultural universal in human society - antipathy towards 'settlers' can spill over into outright hostility and occasionally violence and racism. In some cases, such hostility reduces over time through 'absorption', friendships and intermarriage, so that racial and cultural differences are diminished. Settlers become enlisted in a broadened politics of absorption, also used to strengthen the demographic basis of particular groups, and to provide labour. However, in the early years and decades of newer migrant arrivals, tensions reach high levels in lineage-based societies with strong attachment to place and with inheritance of land and cultural traditions, mediated by kinship, from which settlers are excluded. Ancestral rights are asserted by control over property, and rights to land and resources.

In the Nguti subdivision, a hierarchy of rights to land is still in force, and coloured the negotiations with SGSOC. Over 10 years ago, family relations and traditional family structures were significantly altered as a result of the loss of land to commercial interests. The impact has been profound. It have been particularly severe for settler households and individuals who have neither the cultural and political power nor the network of patronage relationships to mediate and negotiate land acquisition processes in their favour. Ironically, the SGSOC project ultimately failed, overtaken by a lack of capital from the overseas investors, a lack of oil palm infrastructure, and a downsizing of the original land concession. Those who did secure plantation work were dissatisfied and sometimes went unpaid. Despite the change of management between 2015-2016, the entire project is now on hold as conflict and violence has overtaken this region of Cameroon. Prior to this conflict, communities in Nguti subdivision 
were already dispossessed of their land and were unable to fully access and use the lands allocated to SGSOC.

Despite the difficulties experienced during colonial occupation by the Germans (1884-1916), and then the British and the French (1916-1961), the international movement to acquire land for commercial use, which peaked in the last two decades, has intensified the social division between holders of ancestral rights and settlers, disrupting centuries of accommodating settler households among communities in Nguti subdivision.

\section{O N C L U S I O N}

In Cameroon, large land acquisition projects have been facilitated through the government's neoliberal approaches to formalise and commercialise forests and agricultural land. In this process, land is capitalised, commodified, and made available to competing national and international buyers (Boone 2013). Some chiefs, local elites and politicians have been implicated in the process as facilitators and beneficiaries to the detriment of the vast majority. This can be seen through the top-down, elite-dominated approach used to acquire land. The failure of the government to follow due processes in large land negotiations and acquisitions requires that more attention be paid to the interactions between patronage power and lineage, and how these shape the outcomes of large land transactions. We have noted that the actual users of land were largely bypassed in the process; and that the impact of the loss of land has been disproportionately felt by communities who depend on it for livelihoods. Due to the country's socio-cultural stratification in terms of who is a landholder and who is not, we showed that lineage and patronage intersect to determine who benefits, and who does not, during large land acquisitions.

In Nguti subdivision, we showed that most settlers were excluded during land deliberations, and so lost out since they were unavailable to defend their interests. Second, we showed that land acquisitions tend to re-entrench the existing unequal power structures and relationships that exist within communities in favour of chiefly households, those with ancestral rights, and local politicians having traceable ancestral lineage and stronger socio-cultural and political ties as opposed to settler groups without patronage networks and political power to defend their interests. We submit that empirical examination of the impacts of large land acquisitions should consider the centrality of power and patronage networks between landholders and 'settler' households, and how this socio-cultural dichotomy restricts and/or mediates large land acquisition outcomes in Cameroon. It is important to consider how governments in Africa and foreign land investors rely on patronage networks, including some chiefs and local political elites, to act as facilitators of land transactions even when a vast majority of community members have refused to give their consent. In Cameroon, the power of chiefs and local political elites is re-asserted during large land transactions. 


\section{NOTE S}

1. The distinction between indigenes versus non-indigenes is very complex and contested. Based on the Cameroon context, we conceive of indigenes as people with traceable ancestral lineage in the communities where they live prior to colonial rule. Those without ancestral links in the host communities are seen or see themselves as migrants, strangers or settlers - which are also contested terminologies, but with a unifying fact - that they do not have ancestral links to the host communities. Tabe Egbe-Orock (2005: 68) has pointed out that the definition of who is an indigene and who is not, 'often determines who gets what, and when and how they get it in such communities', and that such a distinction is an effort to engender politics that attributes benefits and privileges to certain groups (indigenes) over other groups (migrants, strangers or settlers).

2. During fieldwork, some community members identified themselves as migrants and strangers, even though they clearly stated that they have no intention to return to their places of ancestral origin.

3. A highly pejorative discourse in the local pidgin language that denotes a bodily parasite such as rashes that are resistant to treatment, and just won't go away, no matter how hard the individual tries to get rid of them.

4. As prescribed in Section 16(2) of Ordinance No. 74/74, and in Section 12 of Decree No. 76/166/ 76.

5. It should be noted that the Mbo hinterland is part of the Banyang-Mbo Wildlife Sanctuary. It is very rich in plant and animal species prioritised for conservation. Local communities practice farming, artisanal hunting and harvest forest resources around these areas. The point here is that even though the Mbo hinterland has not been acquired, settlers were overlooked during deliberations.

\section{R E F E R E N C E S}

Achobang, F.C. 2013. 'Cameroon President authorizes Herakles Farms to destroy forests.' <https://www. modernghana.com/news/505760/1/cameroon-president-authorizes-herakles-farms-to-de.html>, accessed 5.1 .2021 .

Baglioni, E. \& P. Gibbon. 2013. 'Land grabbing, large-and small-scale farming: what can evidence and policy from 2oth century Africa contribute to the debate?', Third World Quarterly 34, 9: $155^{8-81 .}$

Batterbury, S.P.J. \& F. Ndi. 2018. 'Land grabbing in Africa', in J.A. Binns, K. Lynch \& E. Nels, eds. Handbook of African Development. London: Routledge.

Bederman, S.H. 1966. 'Plantation agriculture in Victoria, West Cameroon: an historical introduction', Geographical Association 51, 4: 349-6o.

Berry, S. 1984. 'The food crisis and agrarian change in Africa: a review essay', African Studies Review 27, 2: 59-112.

Boone, C. 2013. 'Land regimes and the structure of politics: patterns of land related conflicts', International African Institute 83,1 : 188-203.

Borras, S.M. \& J.C. Franco. 2010. 'Contemporary discourses and contestations around pro-poor land policies and governance', Journal of Agrarian Change 10: 1-32.

Borras, S.M. \& J.C. Franco. 2013. 'Global land grabbing and political reactions 'from below", Third World Quarterly 34: 1723-47.

Borras, S.M., R. Hall, I. Scoones, B. White \& W. Wolford. 2011 . 'Towards a better understanding of global land grabbing: an editorial introduction', Journal of Peasant Studies 38: 209-16.

Bryceson, D.F. 2000. 'Rural Africa at the crossroads: livelihood practices and policies.' ODI Natural Resource Perspectives No. 52. <https://www.odi.org/sites/odi.org.uk/files/odi-assets/publicationsopinion-files / $2859 \cdot$ pdf $>$, accessed 1.4.2020.

Bueger, C \& M. Mireanu. 2015. 'Proximity', in C. Aradau, J. Huysmans, A. Neal \& N. Voelkner, eds. Critical Methods: new frameworks for analysis. London: Routledge, $118-41$.

Collier, P. \& J.A. Venables. 201 2. 'Land deals in Africa: pioneers and speculators.' OxCarre Research Paper 69. Oxford: Oxford Centre for Analysis of Resource Rich Economies.

Cotula, L. 2013. The Great African Land Grab? Agricultural Investments and the Global Food System. London: Zed Books.

Cotula, L. \& S. Vermeulen. 201 1. 'Contexts and procedures for farmland acquisitions in Africa: what outcomes for local people?’, Development $54,1: 40-8$.

Cotula, L., S. Vermeulen, R. Leonard \& J. Keeley. 20o9. Land Grab or Development Opportunity?' Agricultural investment and the global food system. London: IIED, FAO and IFAD. 
Cotula, L., C. Oya, E.A. Codjoe, A. Eid, M. Kakraba-Ampeh, J. Keeley \& W.O. Nasha. 2014 . 'Testing claims about large land deals in Africa: findings from a multi-country study', Journal of Development Studies $5^{\circ}$, 903-25.

Cromwell, E. \& A. Chintedza. 2005. 'Neopatrimonialism and policy processes: lessons from the Southern African food crisis', IDS Bulletin 36, 2. http://www.sarpn.org.za/documents/dooo1 230/Cromwell_ Chintedza_May2005.pdf.

Decree No. $76 / 165$ of 27 April 1976 to Establish Conditions for Obtaining Land Certificates as Amended by Decree No. 2005/048 of 18 th December 2005 .

Deininger, K. \& D. Byerlee. 2011. Rising Global Interest in Farmland: can it yield sustainable and equitable benefits? Washington, DC: World Bank.

Edelman, M. 2013. 'Messy hectares: questions about the epistemology of land grabbing data', Journal of Peasant Studies 40, 3: 485-501.

Fombe, L.F., I. Sama-Lang, L. Fonjong \& A. Mbah-Fongkimeh. 2013. 'Securing tenure for sustainable livelihoods: a case of women land ownership in anglophone Cameroon', Ethics and Economics 10, 2: 73-86.

Fonjong, L., I. Sama-Lang \& F.L. Fon. 2010. 'An assessment of the evolution of land tenure system in Cameroon and its effects on women's land rights and food security', Perspectives on Global Development and Technology 9, 1: 154-69.

Fonjong, L., I. Sama-Lang, L. Fombe \& C. Abonge. 2015. 'Disenchanting voices from within: interrogating women's resistance to large-scale agro-investments in Cameroon.' Paper presented at the Annual World Bank Conference on land and poverty, 23-27 March, Washington, DC.

Fonjong, L., I. Sama-Lang, L. Fombe \& C. Abonge. 2016. 'Land governance and women's rights in largescale land acquisitions in Cameroon', Development in Practice 26, 4: 420-30.

Geschiere, P. 2001, 'Liberalization and new struggles over belonging: towards a recomposition of the village in Africa?', in J.A. Andersson \& M. Breusers, eds. Kinship Structures and Enterprising Actors: anthropological essays on development. Wageningen: Ponsen \& Looijen, 77-95.

Geschiere, P. \& P. Konings, eds. 1993. Itinéraires d'accumulation au Cameroun. Paris: Karthala.

Greenpeace USA. 2013. 'Herakles Farms in Cameroon: a showcase in bad palm oil production.' Washington, DC: Greenpeace.

Hall, R., M. Edelman, S.M. Borras Jr., I. Scoones, B. White \& W. Wolford. 2015. 'Resistance, acquiescence or incorporation? An introduction to land grabbing and political reactions 'from below", Journal of Peasant Studies 42: $467-88$.

Hoyle, D. \& P. Levang. 201 2. 'Oil palm development in Cameroon. An Ad Hoc Working Paper.' Yaoundé: Cameroon WWF in Partnership with IRD and CIFOR.

Joko, M. 20o6. 'Access to economic justice in the Common Law Jurisdiction of Cameroon.' Report for Open Society Institute Africa Governance Monitoring and Advocacy Projects. Yaounde, Cameroon.

Kandel, M. 2015 . 'Politics from below? Small-, mid-and large-scale land dispossession in Teso, Uganda, and the relevance of scale', Journal of Peasant Studies 42: $635^{-} 5^{2}$.

Kaushal, T. 2020. 'Contextually engendering conflict analysis: the case of the Anglophone conflict in Cameroon.' Working paper 11/2020. Geneva: Gender Centre, The Graduate Institute of International and Development Studies.

Konings, P. 1996. 'The postcolonial state and economic and political reforms in Cameroon', in A.E. Fernández Jilberto \& A. Mommen, eds. Liberalization in the Developing World: institutional and economic changes in Latin America, Africa and Asia. London: Routledge.

Konings, P. \& F. Nyamnjoh. 1997. 'The Anglophone problem in Cameroon', Journal of Modern African Studies 35, 2: 207-29.

Linder, J.M. 2013. 'African primate diversity threatened by 'new wave' of industrial oil palm expansion', African Primates $8,25^{-3} 8$.

Mabogunje, A. 1981. The Development Process: a spatial perspective. New York, NY: Holmes and Meier.

Millar, G. 2015 . 'We have no voice for that: land rights, power, and gender in rural Sierra Leone', Journal of Human Rights 14, 4: 445-62.

Moorman, M. \& A. Pitcher. 2014. 'The politics of the belly.' <https://africasacountry.com/2014/05/thepolitics-of-the-belly>, accessed 16.1.2021.

Mope Simo, J.A. 2011. 'Land grabbing, governance and social peace building issues in Cameroon: case study of the roles of elites in land deals and commoditization in North West Region'. Paper presented at the International Conference on Global Land Grabbing, 6-8 April, Institute of Development Studies, University of Sussex, Brighton.

Moreda, T. 2015. 'Listening to their silence? The political reaction of affected communities to large-scale land acquisitions: insights from Ethiopia', Journal of Peasant Studies $4^{2}: 5^{1} 7^{-39}$.

Moreda, T. 201 7. 'Large-scale land acquisitions, state authority and indigenous local communities: insight from Ethiopia', Third World Quarterly 38, 3: 698-716. 
Moreda, T. 2018. 'The right to food in the context of large-scale land investment in Ethiopia', Third World Quarterly 39, 7: 1326-47.

Nature Cameroon. 201 1. 'Critical Observations of the SGSOC ESIA in South West. A Letter Addressed to the Minister of Environment and Nature Protection.' Unpublished manuscript, 8.9.201 1. Nguti: Head Office of Nature Cameroon.

Ndi, F.A. 2013. 'Community resettlement within the context of conservation and development projects: implications on livelihood chances among rural inhabitants of Ikondokondo Village in South West Cameroon.' Master Thesis, Wageningen University. edepot.wur.nl/274410.

Ndi, F.A. 2017. 'Land grabbing, local contestation and the struggle for economic gain: insights from Nguti village, South West Cameroon', Sage Open: 1-14.

Ndi, F.A. 2019a. 'Land grabbing: a gendered understanding of perceptions and reactions from affected communities in Nguti Subdivision of the South West Region of Cameroon', Development Policy Review [online]. doi: $10.1111 /$ dpr.12351.

Ndi, F.A. $2019 b$. 'Land grabbing, gender and access to land: implications for local food production and rural livelihoods amongst affected communities in South West Cameroon', Canadian Journal of African Studies. doi: $10.1080 / 00083968.2018 .1484296$.

Ndi, F.A \& Batterbury, S. 201 7. 'Land grabbing and the axis of political conflicts: insights from South West Cameroon', Africa Spectrum 52, 1: 33-63.

Ngoh, V.T. 1996. Cameroon Since 1800 . Limbe: Press Book.

Nguiffo, S. \& B. Schwartz. 2012. Herakles' $13^{\text {th }}$ Labour? A study of SGSOC's land concession in South West Cameroon. Yaounde: CED.

Ngwasiri, C.N. 2001. 'European legacy of land legislation in Cameroon', in C.M. Lambi \& E.B. Eze, eds. Readings in Geography. Bamenda: Unique Printers.

Nyamjoh, F.B. \& P. Konings. 200o. 'Construction and Deconstruction: Anglophones or autochthones?', in P.N. Nkwi, ed. Anthropology of Africa: Challenges for the $21^{\text {st }}$ Century. Dakar: UNESCO.

Peluso, N.L. \& C. Lund. 2011 . 'New Frontiers of Land Control: introduction', Journal of Peasant Studies 38 , 4: $667-81$.

Pemunta, N.V. 2014. 'New forms of land enclosures: multinationals and state production of territory in Cameroon', Studia UBB Sociologia LIX, 2: $35^{-} 5^{8}$.

Peters, P.E. 2004. 'Inequality and social conflict over land in Africa', Journal of Agrarian Change 4, 3: 269-314.

Ruel, M. 1969. Leopards and Leaders: constitutional politics among a cross river people. London: Routledge.

Ryan, C 2018. 'Large-scale land deals in Sierra Leone at the intersection of gender and lineage', Third World Quarterly 39, 1: 189-206.

Scoones, I., R. Hall, S.M. Borras, B. White \& W. Wolford. 2013. 'The politics of evidence: methodologies for understanding the global land rush', Journal of Peasant Studies 40, 3: 469-83.

Skinner, E.P. 1963. 'Strangers in West African societies', Africa 33, 4: 307-20.

Tabe Egbe-Orock, R. 2005. 'The indigene-settler divide, modernisation and the land question: indications for social (dis)order in Cameroon', Nordic Journal of African Studies 14, 1: 68-78.

Tabe Egbe-Orock, R. 2014. 'Welcoming the 'Fon of Fons': Anglophone elites and the politics of hosting Cameroon's head of state', Africa 84: 226-45.

Thomas, L.M. 2003. Politics of the womb: women, reproduction, and the state in Kenya. Berkeley, CA: University of California Press.

Verma, R. 2014. 'Land grabs, power, and gender in east and southern Africa: so, what's new?' Feminist Economics 20, 1: 52-75.

Vermeulen, S. \& L. Cotula. 2010. 'Over the heads of local people: consultation, consent, and recompense in large-scale land deals for biofuels projects in Africa', Journal of Peasant Studies 37: 899-916.

Wanki, J.E. \& F.A. Ndi. 2019. 'Land grabbing in south-western Cameroon: deconstructing the complexity of local responses', in L. Fonjong, ed. Natural Resource Endowment and the Fallacy of Development in Cameroon. Bamenda: Langaa Publishers.

White, B., S.M. Borras Jr., R. Hall, I. Scoones \& W. Wolford. 201 2. 'The new enclosures: critical perspectives on corporate land deals', Journal of Peasant Studies 39: 619-47.

Wily, A.L. 2011 . 'The law is to blame: the vulnerable status of common property rights in sub-Saharan Africa', Development and Change 42, 3: 733-57.

Wolford, W., S.M. Borras, R. Hall, I. Scoones \& B. White. 2013. 'Governing global land deals: the role of the state in the rush for land', Development and Change 44: 189-210.

Yenshu, E.V. 1998. 'The discourse and politics of indigenous/minority peoples rights in some metropolitan areas of Cameroon', Journal of Applied Social Sciences 1, 1: 59-76.

Zoomers, A. 2010. 'Globalisation and the foreignisation of space: seven processes driving the current global land grab', Journal of Peasant Studies 37: 429-47. 